\title{
AFFCTING OF MORPHOLOGICAL TRAITS ON STEM BORER RESISTANCE IN SOME RICE GENOTYPES

\author{
El-Adl, A. M. ${ }^{1}$; \\ M. Sh. Assas ${ }^{3}$ \\ 1- Genetics Dept., Fac. Agric., Mansoura Univ., Mansoura, Egypt. \\ 2- Rice Res. \& Training Center, Field Crop Res. Inst., ARC, Giza, Egypt. \\ 3- Central Administration for Seed Production, ARC, Giza, Egypt.
}

\begin{abstract}
The rice stem borer (Chilo agamemnon Bles.) is one of the most devastating insects of rice which reducing rice yield in Egypt. The use of resistant rice genotypes remains one of the most reliable methods to control this insect. This investigation aimed to study the mechanisms of resistance (antixenosis, antibiosis and tolerance) in seventeen rice genotypes were evaluated under greenhouse and field conditions. Level of larvae feeding on rice plant was one of the parameter for antixenosis, while weight of larvae or pupae were a measure of antibiosis. Percentage of dead hearts and white heads were used for estimating the tolerance to rice stem borer. The results showed that the hybrid: IR 58025A x Giza $178 \mathrm{R}$ had the highest larval survival percentage, larval weight, pupal weight, dead hearts and white heads. Generally, the hybrid IR 58025A x Giza 178 R and Sakha 101 were the most susceptible and tolerant genotypes, respectively. The tolerant genotypes against stem borer, should have high number of tillers, narrow stem diameter and flag leaf angle. These genotypes could be considered as considers in breeding program to develop new plant type unsuitable for larva stem borer living.
\end{abstract}

\section{INTRODUCTION}

Rice is considered the most popular and important field crop in Egypt and one of the most important cereal crops in the world feeding more than 50 percent of human population (Aidy and Maximos 2005). Among the many biotic and abiotic stresses that influence the yield of rice, plant insects are the most important (Panda and Khush 1995). Application of insecticides causes dangerous affects including: environmental contamination, insect resistant to insecticides, killing fish and poisoning all marines .

The rice stem borer is a major and dangerous insect if it is not controlled. Larva of rice stem borer go into the plant stems and feed on plant nutrients causing, severe crop loss (Sherif, 2002). Rice plants are usually subjected to stem borer infestation at the tillering stage (Soliman and Abd ElBasir, 1997). Therefore, efforts to find resistant genotypes to this insect are very important. The mechanism of tolerance depends on many factors where time and environmental conditions are more important and effective. Resistance to stem borer appears to be under polygenic control (Khush, 1984). Many morphological, anatomical, physiological and biochemical factors have been reported to be associated with resistance and each is controlled by different sets of genes (Chaudhary et al., 1984). Research on rice resistance to insects have been mainly concerned with the rice stem borer. Several high yielding genotypes with multiple resistances to these 


\section{El-Adl, A. M. et al.}

insect have been developed and used in the rice production systems in many countries of the world. Therefore, this research was conducted to investigate the sensitivity and tolerance of new promising hybrids to rice stem borer and to investigate the correlation of insect resistance with morphological characteristics of the rice plants.

\section{MATERIALS AND METHODS}

The present study was carried out at the experimental farm, Rice Research \& Training Center, Sakha, Kafr El-Sheikh, Egypt during 2007, 2008 and 2009 summer seasons. The materials studied were included 17 genotypes, three cytoplasmic male sterile lines viz., IR 69625A, IR 70368A and IR 58025A, as well as, the three restorers: Giza 178 R, Giza 181 R and Giza $182 \mathrm{R}$ and nine hybrid combinations, in addition two commercial rice varieties as checks: one resistant (Sakha 101) and one susceptible (Egyptian yasmine) were raised in a randomized complete blocks design with three replications. Evaluation of antibiosis, at harvest time, 10 hills from each genotype were pulled out with their roots intact and the whole rice plants were dissected to record the number of hibernating larvae. Also, 40 full-grown larvae and 40 pupae were contented from each genotype 10 larvae and 10 pupae per plot. They were freshly weighed.

For evaluation of antixnosis, the larvae survival it was determined by placing 15 first-instar larvae in a glass vial $(6.5 \times 12 \mathrm{~cm})$ containing three inch long stem pieces taken from the basal portion of 70 days old plants. The mouth of vials was covered with screen cloth to allow verifications as well as to prevent larvae from escaping. To keep the stem pieces green and fresh, a thin film of water was left at the bottom of the vials. At 5 day intervals, the stem pieces were replaced with fresh ones of the same genotype until most larvae on susceptible check had pupated. Observation on number of larvae survived, number of larvae died and number of pupae were recorded using three vials for each genotype (Sherif, 2002).

Similarly, the rice traits such as flag leaf angle, stem diameter, number of tillers per plant in different stages of growth were also measured and their relationships with either dead heart or white head were studied. The analyses of data were carried out using SAS statistic package and SPSS software according to Method 1 Model 1 of Griffing (1956) .

\section{RESULTS AND DISCUSSION}

There were significant differences among the genotypes for the studied traits. In Table 1, the highest values for larvae survival percentage, larvae and pupa weight, dead heart and white head for the genotypes IR 58025A (52, 85, 33.8, 18 and 13.28$)$ and IR $58025 \times$ Giza 178 (52, 85, 30.2, 10.55 and 9.63), respectively. While, the lowest values were recorded for in the genotypes resistance check variety Sakha 101(10.5, 46, 20.13, 0.59 and 2.03), respectively. 
Table 1: Mean performance of the estimated traits for seventeen genotypes studied.

\begin{tabular}{|c|c|c|c|c|c|c|c|c|c|}
\hline \multirow[b]{2}{*}{ Genotype } & \multirow{2}{*}{\begin{tabular}{|c|}
$\begin{array}{c}\text { Antix- } \\
\text { enoses }\end{array}$ \\
$\begin{array}{c}\text { Larval } \\
\text { survival }\end{array}$ \\
\end{tabular}} & \multicolumn{5}{|c|}{ Antibioses } & \multicolumn{2}{|c|}{ Tolerance } & \multirow{2}{*}{$\begin{array}{l}\text { Genotype } \\
\text { reaction for } \\
\text { stem borer }\end{array}$} \\
\hline & & $\begin{array}{c}\text { Larval } \\
\text { weight } \\
\text { (mg) }\end{array}$ & \begin{tabular}{|c|} 
Pupa \\
weight \\
(mg)
\end{tabular} & $\begin{array}{l}\text { Flag leaf } \\
\text { angle(ô) }\end{array}$ & $\begin{array}{c}\text { Stem } \\
\text { diameter } \\
(\mathrm{mm})\end{array}$ & $\begin{array}{l}\text { No. of } \\
\text { tillers/ } \\
\text { plant }\end{array}$ & $\begin{array}{l}\text { D. H. } \\
\%\end{array}$ & $\begin{array}{c}\text { W.H. } \\
\%\end{array}$ & \\
\hline \multicolumn{10}{|l|}{ Parental lines } \\
\hline IR 69625A & 22.50 & 50.00 & 24.10 & 18.5 & 10 & 25 & 3.27 & 2.56 & $\mathrm{R}$ \\
\hline IR 70368A & 45.50 & 70.00 & 26.00 & 23.5 & 10.2 & 22.8 & 11.39 & 9.45 & MS \\
\hline IR 58025A & 52.00 & 85.00 & 33.80 & 25.5 & 11.7 & 21.8 & 18.00 & 13.28 & S \\
\hline Giza 178 R & 52.00 & 70.00 & 27.20 & 19.5 & 9.3 & 25.2 & 16.00 & 11.08 & $S$ \\
\hline Giza 181 R & 15.00 & 49.00 & 21.00 & 16 & 8.4 & 26.2 & 2.20 & 1.35 & $\mathrm{R}$ \\
\hline $\begin{array}{l}\text { Giza } 182 \text { R } \\
\text { Hybrids }\end{array}$ & \multicolumn{8}{|c|}{ Hybrids } & MR \\
\hline IR 69625A X Giza 178 R & 30.50 & 53.00 & 28.00 & 26 & 8.6 & 31.2 & 8.95 & 6.35 & MR \\
\hline IR 69625A X Giza 181 R & 22.50 & 51.00 & 22.00 & 24 & 8.1 & 35.2 & 4.35 & 2.18 & $\mathrm{R}$ \\
\hline IR 69625A X Giza 182 R & 25.00 & 52.00 & 25.00 & 25.3 & 8.2 & 32.2 & 4.50 & 4.29 & $\mathrm{R}$ \\
\hline IR 70368A X Giza 178 R & 52.50 & 85.00 & 30.20 & 29.3 & 10 & 28.3 & 10.55 & 9.63 & MS \\
\hline IR 70368A X Giza 181 R & 32.00 & 48.00 & 24.11 & 24 & 9.1 & 32.7 & 6.56 & 5.08 & MR \\
\hline IR 70368A X Giza 182 R & 46.00 & 77.00 & 27.00 & 25.3 & 9.2 & 28.3 & 8.30 & 7.55 & MR \\
\hline IR 58025A X Giza 178 R & 58.50 & 90.00 & 36.60 & 29.5 & 10.7 & 27.5 & 21.78 & 17.65 & HS \\
\hline IR 58025A X Giza 181 R & 37.00 & 55.00 & 29.05 & 29 & 9.1 & 28 & 9.48 & 8.00 & MR \\
\hline $\begin{array}{l}\text { IR 58025A X Giza 182 R } \\
\text { Checks }\end{array}$ & \multicolumn{8}{|c|}{ Checks } & MS \\
\hline Sakha 101 & 10.50 & 46.00 & 20.13 & 14.6 & 7.4 & 26.7 & 0.59 & 2.03 & $\mathrm{R}$ \\
\hline Egyptian yasmine & 50.00 & 82.00 & 29.00 & 34.8 & 9 & 23.7 & 15.05 & 12.10 & S \\
\hline \multirow{2}{*}{ 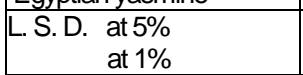 } & 1.15 & 1.36 & 2.49 & 0.67 & 0.16 & 0.84 & 0.40 & 4.25 & \\
\hline & 1.54 & 1.82 & 3.35 & 0.89 & 0.22 & 1.14 & 0.54 & 5.72 & \\
\hline \multicolumn{10}{|c|}{$\begin{array}{l}\text { R = Resistant } \\
\text { MR = Moderately Resistant } \\
\text { HS = Highly Susceptibility } \\
\text { W.H.= white head }\end{array}$} \\
\hline
\end{tabular}

On the other hand, the beast desirable values (16, 8.4 and 26.2) were recorded for flag leaf angle, stem diameter and number of tillers/plant of the check variety Sakha 101 , respectively. While, undesirable values $(25.5,16.0$ and 11.0) were recorded for these traits of IR 58025A, respectively. These results could be concluded that, the flag leaf angle and stem diameter play important role in increasing the resistance to rice stem borer and used as indictor to select for stem borer resistance in early generation.

Correlation data between some traits and rice stem borer infestation are presented in Table 2. Data reveled that, there were a highly significant positive correlation between dead heart, larva survival, Larva weight, pupa weight, Flag leaf angle and Stem diameter, values of correlation were $0.931^{* *}, 0.932^{* *}, 0.899^{* *}, 0.573^{* *}$ and $0.727^{* *}$, respectively. Also, the correlation between white head, larva survival, Larva weight, pupa weight, Flag leaf angle and Stem diameter, the values were $0.731^{\star *}, 0.241 \mathrm{n} . \mathrm{s}$, $0.738^{\star *}, 0.607^{* *}$ and $0.758^{* *}$, respectively. These results indicated that larva survival and pupa weight could be used as a good indicator for resistance to rice stem borer and selection for low value of larva survival and pupa weight could be used in early generations of rice breeding programs. On the contrast, highly significant negative correlation were recorded between dead 
heart and number of tillers per plant, as well as between white head and number of tillers per plant values were $\left(-0.400^{\star *}\right.$ and $\left.-0.419^{* *}\right)$, respectively. Out of these results the line of IR 69625A, Giza 181 R and Sakha 101 it could be as a donor for enhancing the resistance to rice stem borer in hybrid rice breeding program due to the narrow of stem diameter.

Table 2: Correlation matrix between some traits and rice stem borer infestation rates.

\begin{tabular}{|c|c|c|c|c|c|c|}
\hline Variable & $\begin{array}{c}\text { Larva } \\
\text { survival }\end{array}$ & $\begin{array}{c}\text { Larva } \\
\text { weight }\end{array}$ & $\begin{array}{c}\text { Pupa } \\
\text { weight }\end{array}$ & $\begin{array}{c}\text { Flag leaf } \\
\text { angle }\end{array}$ & $\begin{array}{c}\text { Stem } \\
\text { diameter }\end{array}$ & $\begin{array}{c}\text { Number of } \\
\text { tillers/plant }\end{array}$ \\
\hline Dead heart & $0.913^{\star *}$ & $0.352^{\star *}$ & $0.899^{\star *}$ & $0.573^{\star *}$ & $0.727^{\star *}$ & $-0.400^{\star *}$ \\
\hline White head & $0.731^{* *}$ & 0.241 n.s & $0.738^{\star *}$ & $0.607^{* *}$ & $0.718^{* *}$ & $-0.419^{\star *}$ \\
\hline
\end{tabular}

${ }^{*}$ : Significant at $1 \%$ level of probability.

Analysis of variance for insect infestation and morphological traits are presented in Table 3, from this Table significant and highly significant differences among the 14 genotypes tested (9 hybrids, 3 CMS lines and 3 testers) for all studied traits. Parents vs. hybrids mean square indicated that average heterosis was significant in all hybrids for all studied traits under investigation except dead heart, white head and stem diameter.

Concerning the combining ability data revealed highly significant differences among the hybrids and testers for all the traits except stem diameter. The significant and highly significant mean squares of lines $x$ testers for all traits, except stem diameter. The estimate of variance due to GCA was higher than that due to SCA for all traits suggesting greater importance of additive genetic variance (Table 3 ). These results were agreement with El-Mowafi, et.al. (2005).

The estimates of genetic parameters for the eight studied traits Table 4 , indicated that the additive variance $\left(\sigma^{2} A\right)$ and relative importance of GCA\% for all traits were greater than dominance variance $\left(\sigma^{2} D\right)$ and relative importance of SCA\%. The importance of additive gene action for the inheritance of these traits was in agreement with the findings of Ahmed (2004).

Some other morphological traits in rice plants may act as deferent against insect (Panda and Kush, 1995). Rice genotypes with higher tillers and thinner stem diameter such as the genotypes Sakha 101 and Giza 181 R would be tolerant against rice stem borer, because their thin stem diameter which dose not allow larva to feed on plant (Saxena, 1986 and Assas, 2005). Thus, with increasing stem diameter, percentage of infestation was increased, the larval prefers thick stems for feeding. because they have more space and better case. The result of this experiment agrees with the results of Draz (1985) and Hosseini et al, (2011). According to results of this study, about antixnosis resistance, genotypes which had more survival percentage such as the genotypes: IR 58025A x Giza 178 R and Egyptian yasmine were preferred for feeding. In antibiosis mechanism, genotypes that had thick stem such as the genotype: IR 58025A x Giza 178 R showed high larval and pupae weight with an increase in the rate of dead heart and white head. In 
tolerance mechanism, the genotypes with high flag leaf angle, stem diameter and number of tillers per plant had high white head. The results generally showed that product tolerant the genotypes against stem borer, rice plants should have such as high of number of tiller, narrow stem diameter and flag leaf angle should be considered in breeding program to develop new plant type unsuitable for larva stem borer living.

Table 3: Analysis of variance for insect infestation and morphological traits of some rice genotypes studied.

\begin{tabular}{|c|c|c|c|c|c|c|c|c|c|}
\hline & d. & $\begin{array}{l}\text { Larva } \\
\text { survival }\end{array}$ & $\begin{array}{l}\text { Larva } \\
\text { weight }\end{array}$ & $\begin{array}{c}\text { Pupa } \\
\text { weight }\end{array}$ & $\begin{array}{c}\text { Flag } \\
\text { leaf } \\
\text { angle }\end{array}$ & $\begin{array}{c}\text { Stem } \\
\text { diameter }\end{array}$ & $\begin{array}{l}\text { No. of } \\
\text { tillers/ } \\
\text { plant }\end{array}$ & D. $\mathrm{H}$. & W. H. \\
\hline $\operatorname{Reps(R)}$ & 2 & $0.16 n . s$ & 2.07n.s & $0.47 n . s$ & $0.25 n . s$ & $0.001 \mathrm{n} . \mathrm{s}$ & $0.16 n . s$ & $0.07 \mathrm{n} . \mathrm{s}$ & $0.02 n . s$ \\
\hline Genotypes(G) & 14 & $559.85^{\star \star}$ & $727.63^{\star \star}$ & $58.85^{\star \star}$ & $81.88^{\star \star}$ & $2.91^{*}$ & $44.66^{\star *}$ & $95.49^{* \star}$ & $60.57^{\star *}$ \\
\hline Parents & 5 & $755.96^{\star \star}$ & $628.10^{* \star}$ & $62.22^{\star \star}$ & $40.33^{\star \star}$ & $4.21^{\star \star}$ & $8.49^{\star \star}$ & $132.90^{\star \star}$ & $64.89^{* \star}$ \\
\hline Hybrids & 8 & $492.93^{\star \star}$ & $869.08^{\star \star}$ & $57.65^{\star \star}$ & $42.71^{\star \star}$ & $2.05 n . s$ & $27.20^{\star \star}$ & $84^{\star \star}$ & $64.83^{\star \star}$ \\
\hline Parental vs. hybrids & 1 & $114.73^{\star \star}$ & $93.63^{\star \star}$ & $51.57^{\star \star}$ & $603.01^{\star \star}$ & 3.33n.s & $365.17^{\star \star}$ & $0.30 \mathrm{n} . \mathrm{s}$ & 4.80n.s \\
\hline Lines (A) & 2 & $1240.48^{\star \star}$ & $234.33^{\star \star}$ & $125.15^{\star \star}$ & $118.08^{\star \star}$ & $5.50^{*}$ & $66.70^{\star \star}$ & $163^{* \star}$ & $144.33^{\star \star}$ \\
\hline Testers (R) & 2 & $624.48^{\star \star}$ & $2777.33^{\star \star}$ & $97.15^{\star \star}$ & $20.08^{\star \star}$ & $2.21 n . s$ & $23.26^{\star *}$ & $133^{* *}$ & $92.33^{\star \star}$ \\
\hline Lines $x$ testers & 4 & $53.37^{\star \star}$ & $232.33^{\star \star}$ & $4.15^{\star}$ & $16.33^{\star \star}$ & $0.25 n . s$ & $9.43^{\star \star}$ & $20^{* \star}$ & $11.33^{\star \star}$ \\
\hline Error & 28 & 0.51 & 0.71 & 0.30 & 0.08 & 0.01 & 0.28 & 0.07 & 0.02 \\
\hline C. V.\% & & 1.88 & $1 . .30$ & 2.01 & 1.16 & 0.85 & 1.89 & 2.69 & 1.96 \\
\hline GCASCA & & 2.38 & 3.67 & 39.65 & 2.16 & 10 & 2.59 & 4.69 & 6.58 \\
\hline L.S.D at $5 \%$ & & 1.20 & 1.41 & 0.92 & 0.47 & 0.17 & 0.89 & 0.44 & 0.24 \\
\hline at $1 \%$ & & 1.61 & 1.90 & 1.23 & 0.64 & 0.23 & 1.19 & 0.60 & 0.32 \\
\hline
\end{tabular}

*, **: Significant at $5 \%$ and $1 \%$, level of probability, respectively.

n.s: Not significant.

Table 4: Estimates of genetic parameters and heritability in broad and narrow senses for insect infestation and morphological traits.

\begin{tabular}{|c|c|c|c|c|c|c|c|l|}
\hline Parameter & $\begin{array}{c}\text { Larva } \\
\text { survival }\end{array}$ & $\begin{array}{c}\text { Larva } \\
\text { weight }\end{array}$ & $\begin{array}{c}\text { Pupa } \\
\text { weight }\end{array}$ & $\begin{array}{c}\text { Flag leaf } \\
\text { angle }\end{array}$ & $\begin{array}{c}\text { Stem } \\
\text { diameter }\end{array}$ & $\begin{array}{c}\text { No. of } \\
\text { tillers/ } \\
\text { plant }\end{array}$ & D. H. & W. H. \\
\hline $\boldsymbol{\sigma}^{2} \mathbf{A}$ & 195.36 & 283 & 23.77 & 11.73 & 0.80 & 7.90 & 28.45 & 23.78 \\
\hline $\boldsymbol{\sigma}^{2} \mathbf{D}$ & 17.62 & 77.21 & 1.28 & 5.42 & 0.08 & 3.05 & 6.64 & 3.77 \\
\hline $\boldsymbol{\sigma}^{2} \mathbf{E}$ & 0.51 & 0.71 & 0.30 & 0.08 & 0.01 & 0.28 & 0.07 & 0.02 \\
\hline $\boldsymbol{\sigma}^{2} \mathbf{G}$ & 212.98 & 360.21 & 25.05 & 17.15 & 0.88 & 10.95 & 35.09 & 27.55 \\
\hline $\boldsymbol{\sigma}^{2} \mathbf{P}$ & 213.49 & 360.92 & 25.35 & 17.23 & 0.89 & 11.23 & 35.16 & 27.57 \\
\hline$\left(\mathbf{h}_{\mathbf{b}}{ }_{\mathbf{b}} \%\right.$ & 99.76 & 99.80 & 98.82 & 99.54 & 98.88 & 97.51 & 99.72 & 99.93 \\
\hline $\mathbf{( h}_{\mathbf{n}}{ }^{2} \%$ & 91.51 & 78.41 & 93.77 & 68.08 & 89.89 & 70.35 & 80.92 & 86.25 \\
\hline $\mathbf{g c a} \%$ & 91.73 & 78.57 & 94.89 & 68.40 & 90.91 & 72.15 & 81.08 & 86.32 \\
\hline $\mathbf{s c a} \%$ & 8.27 & 21.43 & 5.11 & 31.60 & 9.09 & 27.85 & 18.92 & 13.68 \\
\hline
\end{tabular}

gca is relative importance of gca $\%=\sigma^{2} A / \sigma^{2} G$ sca is relative importance of sca\% $=\sigma^{2} D / \sigma^{2} G$ 


\section{REFERENCES}

Ahmed, A. M. R. (2004). Genetical studies on some hybrids of rice. M. Sc. Thesis. Fac. Agric., Mansoura Univ. 120pp.

Aidy, I.R. and M.A. Maximos ( 2005). Rice varietal improvement in Egypt during the last two decades: Achievements and Future strategies. Egypt. J. Agric, Res., 83 (5A).

Assas, M. Sh. (2005). Ecological studies on insect rice fauna. M. Sc. Thesis, Fac. of Agric., Kafr El-Sheikh. Tanta Univ. 125pp.

Chaudhary, R. C.; G. S. Khush and E. A. Heinrichs (1984). Varietal resistance to rice stem borers in Asia. Insect Sci. Appl., 5: 447-463.

Draz, A. E. (1985). Genetic studies on rice. Genetical studies on some qualitative and quantitative characters in rice. Ph. D. Thesis, Fac. of Agric., Kafr El-Sheikh, Tanta Univ., 163pp.

El-Mowafi, H. F., A. O. Bastawisi, M. I. Abo Youssef and F. U. Zaman (2005). Exploitation of rice heterosis under Egyptian conditions. Egypt. J. Agric, Res., 83 (5A).

Griffing, B. (1956). Concept of general and specific combining ability in relation to diallel crossing system. Austr. J. Bio. Sci. 9: 463-493.

Hosseini, S. Z.; N. B. Jelodar; N. Bagheri; F. Alinia and T. Osku (2011). Traits affecting the resistance of rice genotypes to rice stem borer. International Journal of Biology, 3 (1): 130-135.

Khush, G. S. (1984). Breeding rice for resistance to insects. Protection Ecol., 7: $147-165$.

Panda, N. and G. S. Khush (1995). Breeding for resistance to insects. In: Host plant resistance to insects, 324 - 355 pp., International Rice Research Institute, Philippines, Los Banos.

Saxena, R. C. (1986). Biochemical bases of insect resistance in rice varieties. In: Natural resistance of plants to pests: Roles of Allelochemicals. ACS Symposium Series, 142-159.

Sherif, M. R. (2002). Rice insect pests. Rice in Egypt, 248-286pp. (ed. T. Castillo). Rice Research and Training Center, Agric. Res. Center, Egypt.

Soliman, A. M. and S. Abd El-Basir (1997). Varietal resistance: Biological evaluation and screening of certain rice entries against the rice stem borer, Chilo agamemnon Bles. Egypt. J. Agric. Res., 75 (1): 165-172. 
تأثير الصفات المورفولوجية على مقاومة ثاقبة السـاق فى بعض التراكيب الوراثيـة لكلأرز

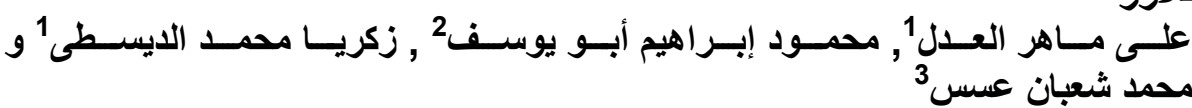

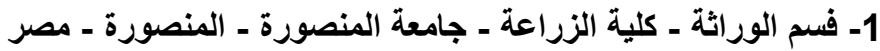

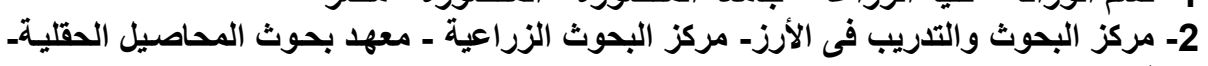

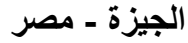
3- الإدارة المركزية لإنتاج التقاوى ـ مركز البحوث الزراعية ـ الجيزة ـ مصر

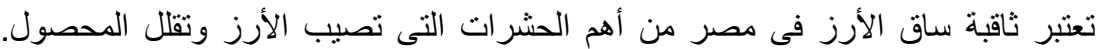

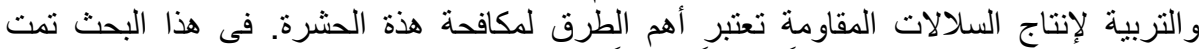

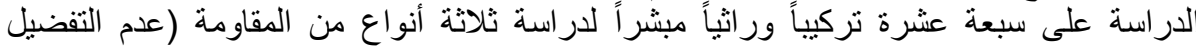

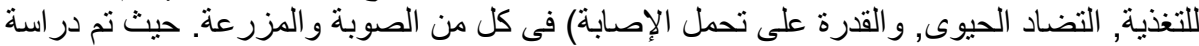

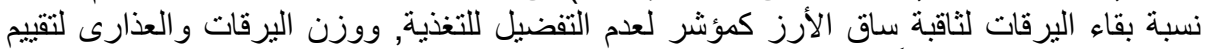

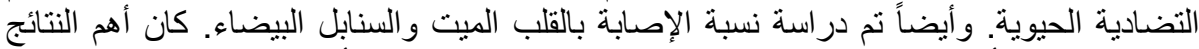

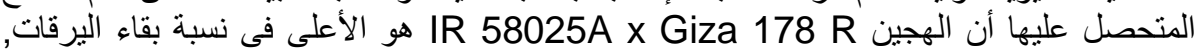

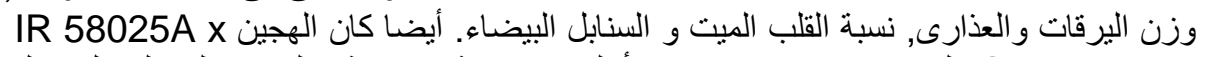

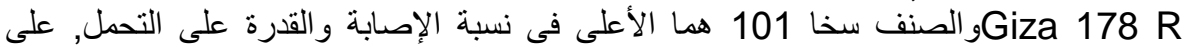

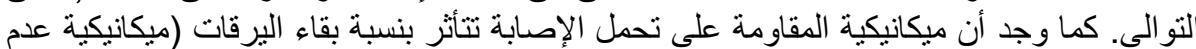

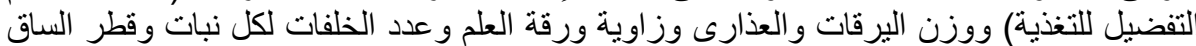

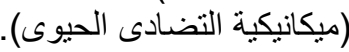

كلية الزراعة - جامعة المنصورة مركز البحوث الزراعية
قام بتحكيم البحث

أ.د / ممدوح محمد عبد المقصود أ.د / إبر / إهيم رزق مدم عايدى 